\title{
Bibliografía sobre la obra de Manuel Vázquez Montalbán
}

Bibliografía electrónica en acceso abierto con más de 1100 entradas administradas por la Biblioteca de la Universidad de Oslo junto con la Asociación de Estudios Manuel Vázquez Montalbán.

Las entradas incluyen referencias bibliográficas de artículos, capítulos de libros, tesis doctorales, tesis de maestría, introducciones, prólogos y epílogos de libros, reseñas, etc. que tratan acerca de la extensa obra de

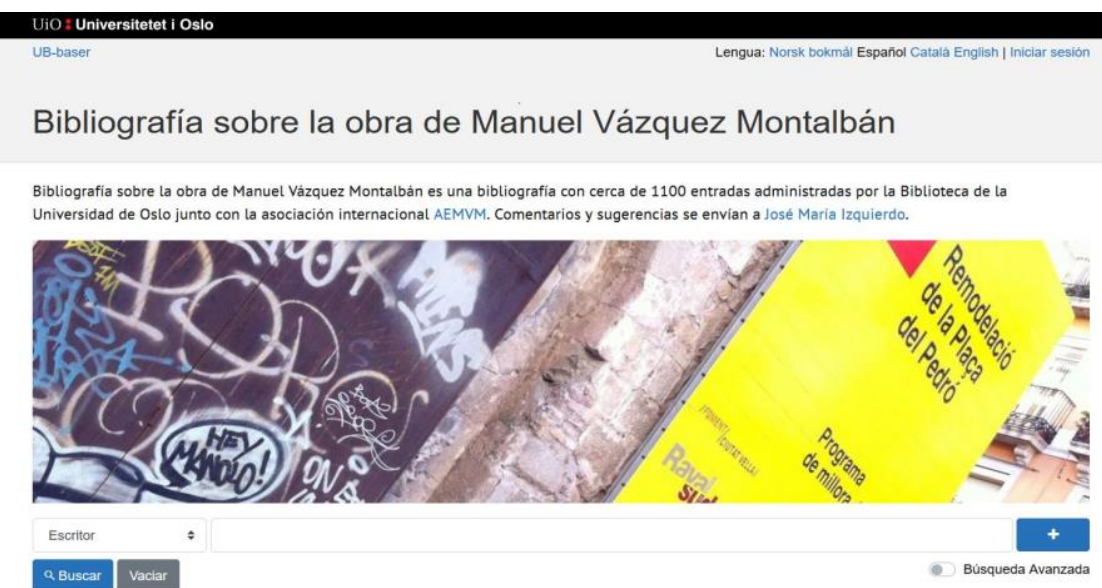

Manuel Vázquez Montalbán.

El interfaz de este banco de datos está en Catalán, Español, Inglés y Noruego. Su utilización es totalmente gratuita y su dirección es: https://ub-baser.uio.no/bibliomanuel. 